\title{
KANDUNGAN PROKSIMAT, ASAM SIANIDA, ASAM FITAT DAN TEKSTUR TAHU KEDELAI (Glycine max)-KORO PEDANG PUTIH (Canavalia ensiformis) DENGAN PENGGUMPAL ASAM ASETAT
}

\author{
PROXIMATE, CYANIDE ACID, PHYTIC ACID CONTENT AND TEXTURE OF SOY \\ (Glycine max)-JACK BEAN (Canavalia ensiformis) TOFU COAGULETED USING ACETIC \\ $A C I D$
}

\author{
Dwi Ishartani ${ }^{\left.1,2^{*}\right)}$, Dian R. Affandi ${ }^{1)}$, Bambang S. Amanto ${ }^{1)}$, Puji P. Rahayu ${ }^{1)}$ \\ 1) Program Studi Ilmu dan Teknologi Pangan Fakultas Pertanian Universitas Sebelas Maret \\ 2) Pusat Penelitian dan Pengembangan Pangan Gizi dan Kesehatan Masyarakat Universitas Sebelas Maret \\ *email: dwiishartani@staff.uns.ac.id
}

Diserahkan [3 Desember 2019]; Diterima [30 Januari 2020]; Dipublikasi [16 Februari 2020]

\begin{abstract}
The aim of this study was to determine the effect of acetic acid concentration as coagulant to the proximate, cyanide acid, phytic acid content and texture of soy-jack bean tofu. This study used a one-factor Randomized Complete Design that is the concentration of acetic acid (0.20\%; 0.25\%; and 0.30\%). Samples were prepared in three replications and the resulting data were analyzed statistically using One Way ANOVA followed by DMRT ( $\alpha: 5 \%)$ if there were significant differences. The results showed that an increase in the concentration of acetic acid produced tofu with higher levels of cyanide acid and $F$ max but lower water and ash levels. The concentration of acetic acid did not affect the levels of protein, fat, and phytic acid of soy-jack bean tofu produced.
\end{abstract}

Keywords: Canavalia ensiformis, tofu, acetic acid, cyanide acid

\begin{abstract}
ABSTRAK
Tujuan penelitian ini adalah mengetahui pengaruh konsentrasi asam asetat sebagai penggumpal terhadap kandungan proksimat, asam sianida, asam fitat dan tekstur tahu kedelai-koro pedang. Penelitian ini menggunakan Rancangan Acak Lengkap satu faktor yaitu konsentrasi asam asetat $(0,20 \% ; 0,25 \% ;$ dan $0,30 \%)$. Sampel disiapkan dalam tiga ulangan dan data yang dihasilkan dianalisis secara statistic menggunakan One Way ANOVA yang dilanjutkan dengan DMRT ( $\alpha: 5 \%)$ jika terdapat beda nyata. Hasil penelitian menunjukkan bahwa peningkatan konsentrasi asam asetat menghasilkan tahu dengan kadar asam sianida dan $F$ max yang semakin tinggi tetapi kadar air dan abu yang semakin rendah. Konsentrasi asam asetat tidak berpengaruh terhadap kadar protein, lemak, dan asam fitat tahu kedelai-koro pedang putih yang dihasilkan.
\end{abstract}

Kata Kunci : Canavalia ensiformis, tahu, asam asetat, asam sianida

\section{PENDAHULUAN}

Tahu merupakan salah satu produk olahan kedelai selain tempe, tauco, dan kecap yang sangat digemari di Indonesia. Menurut Shurtleff dan Aoyagi (1975) tahu adalah produk turunan kedelai yang tinggi protein berbentuk gel hasil koagulasi protein larut air dari kedelai. Komponen utama tahu terdiri dari protein yang terekstrak, di samping air, lemak, vitamin, dan mineral. Dominasi kedelai sebagai bahan baku tahu dan tempe menjadikan volume import kedelai di Indonesia terus mengalami peningkatan. BPS (2019) melaporkan bahwa import kedelai Indonesia pada tahun 2010 sebesar 1.740.504,7 ton dan pada tahun 2018 meningkat menjadi $2.585 .809,1$ ton.
Selain kedelai, tahu juga dapat dibuat dari koro-koroan. Penggunaan leguminosa non kedelai sebagai bahan baku pembuatan tahu dan tempe berpotensi menekan kebutuhan kedelai dalam negri Indoneasia. Beberapa jenis koro yang pernah digunakan dalam penelitian pembuatan tahu adalah koro komak (Ratnaningtyas, 2003) dan koro kerandang (Djaafar et al., 2010). Koro pedang putih adalah salah satu legum yang jarang digunakan dan sering diabaikan. Legum jenis ini kaya akan protein dan nutrisi lainnya seperti pati, serat pangan, fitokimia, minyak, vitamin, dan elemen mineral. Biji koro pedang matang memiliki kadar protein kasar yang tinggi (20-32\%) (Eke et al., 2007). Dengan kandungan protein yang tinggi maka diharapkan koro pedang dapat 
digunakan sebagai bahan dasar pembuatan tahu. Namun demikian, menurut laporan Rahayu (2014) curd tahu belum dapat terbentuk dari koro pedang putih $100 \%$. Koro pedang putih baru dapat digunakan sebagai bahan pensubstitusi kedelai dalam proses pembuatan tahu. Curd tahu yang kompak baru dapat terbentuk ketika koro pedang putih dicampur dengan kedelai dengan proporsi 1:4. Koro pedang yang dicampur dengan kedelai dengan proporsi 1:1 masih menghasilkan curd yang rapuh yang hancur ketika digoreng.

Menurut Supriadi (2003), proses pembuatan tahu meliputi sortasi bahan baku kedelai, penimbangan, perendaman, penggilingan, perebusan, penyaringan, penggumpalan dan pencetakan dengan atau tanpa pengepresan. Ekstraksi kedelai pada pembuatan tahu, pada prinsipnya sama dengan susu kedelai. Susu kedelai yang diperoleh dari ekstraksi dan penyaringan kemudian digumpalkan dengan cara menambahkan larutan asam. Larutan asam yang biasa digunakan adalah asam asetat atau cuka makan dan asam laktat. Sebagai zat penggumpal secara tradisional biasanya digunakan biang, yaitu cairan yang keluar pada waktu pengepresan dan sudah diasamkan semalam.

Menurut Suprapti (2004) pada proses pembuatan tahu terdapat beberapa faktor yang mempengaruhi rendemen dan mutu tahu yang dihasilkan antara lain pemilihan bahan baku, bahan penggumpal dan cara penggilingan. Akan tetapi, Shurleff dan Aoyagi (1975) menekankan bahwa penggumpalan adalah langkah terpenting dalam pembuatan tahu. Salah satu cara penggumpalan yang dilakukan adalah dengan menggunakan asam. Winarno (2002) menyatakan bahwa asam akan menurunkan $\mathrm{pH}$ bahan pangan sehingga cukup untuk menyebabkan denaturasi protein. Menurut Shurtleff dan Aoyagi (1975) bahan penggumpal tipe asam akan menghasilkan kualitas tahu yang lebih baik dengan rendemen tahu yang lebih tinggi dibandingkan dengan penggumpal tipe garam.

Selain jenis penggumpal, konsentrasi penggumpal juga merupakan faktor penting pada saat proses penggumpalan tahu. Asam asetat yang digunakan untuk penggumpal tahu biasanya memiliki konsentrasi 5\% dan diberikan sebanyak kurang lebih 16\% dari berat kedelai kering yang digunakan (Supriadi, 2003). Konsentrasi asam asetat dalam menggumpalkan susu kedelai telah banyak diteliti. Kebanyakan dari literatur menyebutkan bahwa asam asetat yang digunakan biasanya berkadar 5\% (Supriadi, 2003; Prabhakaran et al., 2005). Sedangkan menurut Sidar et al. (2009) pada konsentrasi $0,18 \%$ asam asetat sudah menunjukkan pembentukan curd kedelai dengan baik dan merupakan konsentrasi limit untuk asam asetat, serta membuktikan bahwa perbedaan konsentrasi asam asetat akan menghasilkan karakteristik tahu yang berbeda. Konsentrasi asam asetat juga dilaporkan mempengaruhi intensitas kekenyalan, aroma asam, rasa asam, dan aftertaste pahit pada tahu kedelai yang disubstitusi koro pedang putih (Ishartani, 2017).

Penelitian ini mengkaji pembuatan tahu berbasis kedelai yag disubstitusi koro pedang putih menggunakan penggumpal asam asetat dalam berbagai konsentrasi. Penelitian ini bertujuan mengetahui pengaruh konsentrasi asam asetat terhadap kandungan gizi (proksimat), anti gizi (asam sianida dan asam fitat) serta tekstur ( $F$ max ) tahu kedelai yang disubstitusi koro pedang putih.

\section{METODE PENELITIAN}

\section{Bahan}

Bahan baku yang digunakan dalam penelitian ini adalah kedelai yang diperoleh dari pasar lokal Surakarta dan koro pedang yang diperoleh dari LSM Gita Pertiwi, Surakarta. Bahan penggumpal asam asetat yang digunakan adalah cuka makan komersial merk "Dixi". Bahan kimia yang digunakan untuk analisis meliputi $\mathrm{H}_{2} \mathrm{SO}_{4}$, $\mathrm{K}_{2} \mathrm{~S}_{2} \mathrm{O}_{4}, \mathrm{HgO}, \mathrm{CuSO}_{4}, \mathrm{NaOH}, \mathrm{K}_{2} \mathrm{~S}$, indikator metil merah, $\mathrm{HCl}, \mathrm{Zn}, \mathrm{KOH}$, alkalin pikrat $(0,25 \%$ asam pikrat dibasakan dengan $\mathrm{Na}_{2} \mathrm{CO}_{3}$ hingga pH 11), $\mathrm{KCN}, \mathrm{HNO}_{3}, \mathrm{FeCl}_{3}$, amil alkohol, dan amonium tiosianat. Semua bahan kimia merupakan produk Merck, kecuali asam pikrat merupakan produk Sigma. 


\section{Alat}

Alat yang digunakan pada pembuatan tahu kedelai-koro pedang putih adalah blender, cetakan tahu, dan kain saring. Sedangkan alat yang digunakan pada analisis adalah timbangan analitik (Ohaus Adventure), oven (Memmert), desikator, cawan porselen, tanur (Bransstead Thermolyne), labu Kjeldahl, sentifuge, spektrofotometer UV-mini 124, vortex, Soxhlet (Iwaki PyrexTe-32), waterbath, dan alat-alat gelas.

\section{Tahapan Penelitian}

Metode pembuatan tahu mengikuti Ishartani (2017). Tahu segar yang diperoleh sebagian dianalisis kadar air (AOAC, 1970), asam sianida (AOAC 1970) dan asam fitat (Davies dan Reid, 1979), dan sebagian lagi dikeringkan menggunakan freeze dryer sebelum dianalisis kadar abu (AOAC, 1970), kadar protein total (AOAC, 1970), dan kadar lemak (AOAC, 1970).

Rancangan percobaan yang digunakan adalah Rancangan Acak Lengkap menggunakan satu faktor, yaitu konsentrasi asam asetat. Sampel tahu kedelai-koro pedang putih disiapkan dalam tiga tiga kali ulangan dengan masing-masing dianalisis dua kali. Pengaruh konsentrasi asam asetat dianalisis menggunakan Analysis of Variance (ANOVA) melalui program SPSS 16.0. Jika terdapat beda nyata maka dilanjutkan dengan Duncan Multiple Range Test (DMRT) pada $\alpha: 5 \%$.

\section{HASIL DAN PEMBAHASAN}

\section{Kandungan Proksimat}

Data kadar air pada Tabel 1 menunjukkan bahwa konsentrasi asam asetat berpengaruh terhadap kadar air tahu kedelaikoro pedang. Semakin tinggi konsentrasi asam asetat maka semakin rendah kadar air tahu yang dihasilkan. Prabhakaran et al. (2006) menyebutkan bahwa asam asetat merupakan penggumpal yang memiliki kecepatan penggumpalan yang tinggi. Oleh karena itu proses koagulasi berjalan semakin cepat seiring meningkatnya konsentrasi sehingga semakin banyak whey yang terbuang dan semakin sedikit air yang terperangkap di dalam tahu. Harmayani et al. (2009) menambahkan bahwa asam asetat dapat menggumpalkan protein hingga $67,8 \%$, lebih tinggi dibandingkan dengan asam laktat yang hanya mampu menggumpalkan $55 \%$ protein. Semakin banyak protein yang digumpalkan maka semakin banyak protein terperangkap di dalam curd dan air banyak dibebaskan bersama whey.

Kadar abu tahu kedelai-koro pedang putih juga dipengaruhi oleh konsentrasi asam asetat (Tabel 1). Hal ini diduga disebabkan oleh semakin banyaknya abu yang terlarut dalam whey pada saat penggumpalan dan pencetakan tahu. Semakin tinggi konsentrasi asam asetat yang diikuti semakin sempurnanya pemisahan whey maka semakin banyak abu yang ikut terbuang bersama whey. Penggunaan asam asetat 0,30\% menghasilkan tahu dengan karakteristik kadar abu yang mendekati standar SNI, yaitu maksimal 1,0\% (BSN, 1998). Namun demikian, kisaran kadar abu tahu kedelaikoro pedang putih pada penelitian ini mirip dengan yang dilaporkan oleh Sidar et al. (2009) yang menyatakan bahwa kadar abu tahu dengan penggumpal asam berada di kisaran 2,42\%-2,76\%.

Tabel 1 menunjukkan konsentrasi asam asetat tidak mempengaruhi kadar protein tahu kedelai-koro pedang putih. Kadar protein tahu kedelai-koro pedang putih pada penelitian ini lebih rendah dibandingkan tahu substitusi komak (Ratnaningtyas, 2003) tetapi lebih tinggi dibandingkan tahu substitusi kacang tunggak (Rosida et al., 2011) dan tahu substitusi koro pedang (Susanti et al., 2013).

Data pada Tabel 1 juga menunjukkan bahwa konsentrasi asam asetat tidak memiliki pengaruh nyata terhadap kadar lemak tahu kedelai-koro pedang putih. Kadar lemak tahu kedelai-koro pedang putih dalam penelitian ini jauh lebih besar daripada tahu substitusi koro pedang sebesar 2,97\% (Susanti et al., 2013) dan tahu substitusi koro komak sebesar 32-33\% (Ratnaningtyas, 2003). 
Tabel 1 Kandungan Proksimat, Asam Sianida, dan Asam Fitat Tahu Kedelai-Koro Pedang Putih

\begin{tabular}{crrr}
\hline \multirow{2}{*}{ Komponen } & \multicolumn{3}{c}{ Konsentrasi Asam Asetat $^{*}$} \\
\cline { 2 - 4 } & \multicolumn{1}{c}{$0,20 \%$} & \multicolumn{1}{c}{$0,25 \%$} & $0,30 \%$ \\
\hline Air $(\% \mathrm{wb})$ & $80,00^{\mathrm{c}} \pm 0,35$ & $78,91^{\mathrm{b}} \pm 0,04$ & $76,40^{\mathrm{a}} \pm 0,32$ \\
Abu (\%db) & $2,01^{\mathrm{b}} \pm 0,12$ & $1,17^{\mathrm{a}} \pm 0,06$ & $1,04^{\mathrm{a}} \pm 0,06$ \\
Protein total (\%db) & $48,19^{\mathrm{a}} \pm 0,58$ & $48,54^{\mathrm{a}} \pm 0,76$ & $49,30^{\mathrm{a}} \pm 0,48$ \\
Lemak (\%db) & $41,37^{\mathrm{a}} \pm 1,25$ & $39,61^{\mathrm{a}} \pm 2,61$ & $38,47^{\mathrm{a}} \pm 3,22$ \\
HCN (ppm) & $9,98^{\mathrm{a}} \pm 0,39$ & $11,84^{\mathrm{b}} \pm 0,58$ & $15,23^{\mathrm{c}} \pm 0,39$ \\
Asam fitat (mg/g) & $0,05^{\mathrm{a}} \pm 0,01$ & $0,05^{\mathrm{a}} \pm 0,00$ & $0,06^{\mathrm{a}} \pm 0,003$ \\
\hline
\end{tabular}

*angka menunjukkan nilai rata-rata \pm standar deviasi; angka yang diikuti huruf yang berbeda pada baris yang sama menyatakan ada beda nyata pada $\mathrm{p}<0,05$

Kandungan Asam Sianida dan Asam Fitat

Konsentrasi asam asetat terlihat berpengaruh nyata terhadap kadar asam sianida (HCN) tahu kedelai-koro pedang putih (Tabel 1). Semakin tinggi konsentrasi asam asetat maka semakin tinggi kadar asam sianida yang masih tersisa di tahu substitusi koro pedang. Hal ini disebabkan oleh sifat asam sianida yang mudah bereaksi dengan asam karena asam sianida ( $\mathrm{HCN})$ merupakan asam lemah yang mudah berkonversi menjadi ion $\mathrm{CN}$ dan sebaliknya (Newhouse, 2010). Pembuatan tahu melalui proses penambahan air sehingga HCN dapat terurai menjadi ion $\mathrm{H}^{+}$dan $\mathrm{CN}^{-}$. Semakin banyak asam yang ditambahkan maka semakin banyak ion $\mathrm{CN}^{-}$yang terkonversi menjadi HCN kembali. Asam sianida ini akan terperangkat di curd dan tidak larut dalam whey pada saat pengepresan. Kadar asam sianida pada tahu kedelai-koro pedang putih ini sudah di bawah 50 ppm sehingga aman dikonsumsi (Winarno, 2002). Kadar asam sianida tahu kedelai-koro pedang putih ini lebih rendah dibandingkan dengan tahu substitusi koro kerandang 25\% dengan penggumpal asam laktat $2 \%$ (115 ppm)
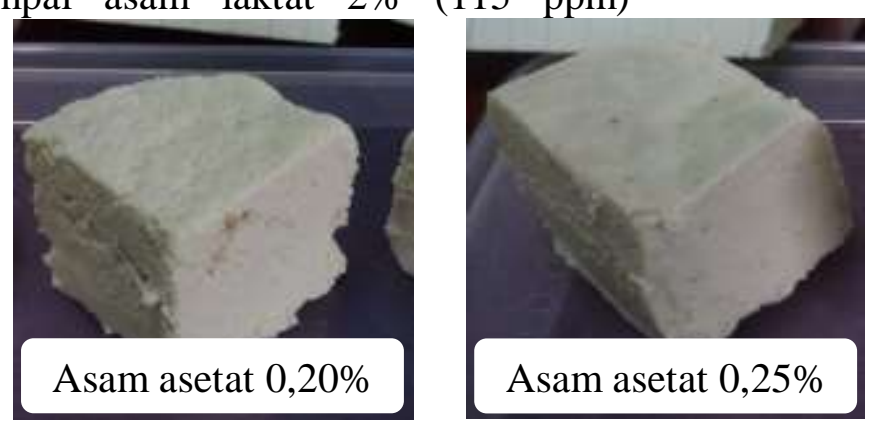

Gambar 1. Kenampakan Tahu Kedelai-Koro Pedang Putih dengan Berbagai Konsentrasi Penggumpal Asam Asetat
(Djaafar et al., 2010). Tabel 1 menunjukkan konsentrasi asam asetat tidak berpengaruh terhadap kadar asam fitat tahu kedelai-koro pedang putih.

\section{Tekstur}

Salah satu uji fisik untuk mengetahui tekstur tahu dapat dilakukan dengan menggunakan alat Lloyd Universal Testing Machine. Dengan alat tersebut, nilai teksur sampel tahu dinyatakan dalam parameter $F$ max yang menunjukkan kekerasan sampel. Tabel 2 menunjukkan semakin tinggi konsentrasi asam asetat yang digunakan maka semakin besar nilai $F$ max tahu kedelai-koro pedang putih yang dihasilkan. Hasil ini sejalan dengan hasil penilaian tekstur secara sensoris menggunakan uji perbandingan jamak, dimana intensitas kekenyalan tahu kedelai-koro pedang putih meningkat seiring dengan meningkatnya konsentrasi asam asetat yang digunakan (Ishartani, 2017). Semakin tinggi konsentrasinya maka akan meningkatkan sineresis dan whey yang hilang semakin banyak seiring dengan semakin kompaknya matriks protein (Sidar et al., 2009). 
Tabel 2 Hasil Analisis $F \max$ Tahu Kedelai-Koro Pedang Putih

\begin{tabular}{cc}
\hline Konsentrasi Asam & $F \max (\mathrm{N})^{*}$ \\
\hline $0,20 \%$ & $2,35^{\mathrm{a}} \pm 0,16$ \\
$0,25 \%$ & $2,36^{\mathrm{a}} \pm 0,15$ \\
$0,30 \%$ & $3,63^{\mathrm{b}} \pm 0,20$ \\
\hline
\end{tabular}

* angka menunjukkan nilai rata-rata \pm standar deviasi; angka yang diikuti huruf yang berbeda pada baris yang sama menyatakan ada beda nyata pada $p<0,05$

Nilai $F \max$ tahu kedelai-koro pedang putih dengan penggumpal asam asetat $0,20 \%$ dan $0,25 \%$ dalam penelitian ini memiliki nilai $F \max$ yang lebih rendah dibandingkan F max tahu substitusi koro kerandang dengan berbagai jenis penggumpal yang berkisar 3,60 N-9,44 N (Djaafar et al., 2010) maupun tahu kedelai dengan penggumpal asam asetat sebesar 4,80 N (Sidar et al., 2009). Akan tetapi, nilai $F$ max tahu kedelai-koro pedang putih dengan penggumpal asam asetat $0,30 \%$ hampir sama dengan tahu substitusi kerandang dengan penggumpal ekstrak nanas sebesar 3,60 N (Djaafar et al., 2010). Kenampakan tahu kedelai-koro pedang putih dapat dilihat pada Gambar 1.

\section{KESIMPULAN}

Konsentrasi asam asetat berpengaruh terhadap kadar air, abu, asam sianida dan tekstur ( $F$ max), tetapi tidak berpengaruh terhadap kadar protein, lemak, dan asam fitat tahu kedelai-koro pedang putih. Semakin tinggi konsentrasi asam asetat maka semakin tinggi kadar asam sianida dan nilai $F$ max, serta semakin rendah kadar air dan abu tahu kedelai-koro pedang putih.

\section{DAFTAR PUSTAKA}

AOAC. 1970. Official Methods of Analysis of the Association of Official Analytical Chemist. Analysis of the Association of Official Analytical Chemist, Washington DC.

Badan Pusat Statistik. (2019). Impor Kedelai Menurut Negara Asal Utama, 20102018.

https://www.bps.go.id/statictable/2019/ 02/14/2015/impor-kedelai-menurut- negara-asal-utama-2010-2018.html. [10 Januari 2020].

BSN [Badan Standarisasi Nasional]. 1998. Standar Nasional Indonesia 01-31421998: Tahu. Badan Standardisasi Nasional, Jakarta.

Davies, N. T. dan Reid, H.. 1979. An Evaluation of Phytate, Zinc, Copper, Iron and Manganase Contents of and Zn Availability From Soya Based Tectured -Vegetable - Protein Meat Subtitutes or Meat Extenders. Br. J. Nutr. 41 : 579-589.

Djaafar, T. F., Cahyaningrum, N., dan Purwaningsih, H. 2010. Physicochemical Characteristics of Tribal Beans (Canavalia virosa) and its Alternative Tofu and Tempeh Food Product. Indonesian Journal of Agricultural Science 11 (2): 74-80.

Eke, C. N. U., Asoegwu, S. N., dan Nwandikom, G. I. 2007. Some Physical Properties of Jackbean Seed (Canavalia ensiformis). The CIGR Ejournal Manuscript FP 07014 Vol. IX : $1-11$

Harmayani, E., Rahayu, E. S., Djaafar, T. F., Sari, C. A., Marwati, T. 2009. Pemanfaatan Kultur Pediococcus Acidilactici F-11 Penghasil Bakteriosin Sebagai Penggumpal pada Pembuatan Tahu. Jurnal Pascapanen 6 (1): 10-20.

Ishartani, D., Amanto, B.S., Affandi, D. R., Rahayu, P.P. 2017. Karakteristik Sensoris Tahu Kedelai (Glycine max) Substitusi Koro Pedang Putih (Canavalia ensiformis) dengan Penggumpal Asam Asetat. Prosiding Seminar Nasional dalam Rangka Dies Natalis UNS ke-41 "Peran Sumber Daya Pertanian, Perkebunan dan Peternakan dalam Mendukung Ketahanan Pangan Nasional, Universitas Sebelas Maret Surakarta.

Pansegrau, W., Lanka, E., Barth, P.T., Figurski, D.H., Guiney, D.G., Haas, D., Helinski, D.R., Schwab, H., Stanisisch, V.A. dan Thomas, C.M. (1994). Complete nucleotide sequence of 
Birmingham IncP $\alpha$ plasmids. Compilation and comparative analysis. Journal of Molecular Biology 239: 623663.

Prabhakaran, M. P., Perera C. O., Valiyaveettil, S. 2006. Effect of Different Coagulant on the Isoflavones Levels and Physical Properties of Prepared Firm Tofu. Food Chemistry 99 (3) : 492-499

Rahayu, P. P. 2014. Kajian Karakteristik Fisikokimia dan Sensori Tahu Substitusi Koro Pedang (Canavalia ensiformis) dengan Penggumpal Asam Asetat. Skripsi Fakultas Pertanian UNS, Surakarta.

Ratnaningtyas, A. 2003. Tahu dari Kacang Non-kedelai: Studi Kasus Kacang Komak. Skripsi Fakultas Teknologi Pertanian IPB, Bogor.

Rosida, D. F., Hardiyanti, Q., Murtiningsih. 2011. Kajian Dampak Substitusi Kacang Tunggak pada Kualitas Fisik dan Kimia Tahu. REKAPANGAN 5 (2) : 138-149

Shurtleff, W. dan A. Aoyagi. 1975. The Book of Tofu: Food for Mankind Volume 1. Autumn Press.USA.
Sidar, A., Utami, I.S., Rahayu, S., dan Rahayu, E.S. 2009. Tofu Characterization Using Acid and Salt Coagulants in Industrial Scale. Proceeding The $3^{\text {rd }}$ International Conference of Indonesia Society for Lactic Acid Bacteria. Yogyakarta.

Suprapti, L. M., 2004. Teknologi Pengolahan Panga: Pembuatan Tahu. Kanisius, Yogyakarta.

Supriadi, G. 2003. Membuat Susu Kedele dan Tahu. Direktorat Pendidikan Menengah Kejuruan, Direktorat Jenderal Pendidikan Dasar dan Menengah, Departemen Pendidikan Nasional, Jakarta.

Susanti, I., Hasanah, F., Siregar, N. C., Supriyatna, D. 2013. Potensi Kacang Koro Pedang (Canavalia ensiformis DC) Sebagai Sumber Protein Produk Pangan. Jurnal Riset Industri 7(1) : 113.

Winarno, F. G. 2002. Kimia Pangan dan Gizi. PT. Gramedia Pustaka Utama, Jakarta. 